\title{
The buildings of the John Paul II Centre - a challenge for civil engineering and architecture
}

\author{
Bogumil Wrana ${ }^{1}$, Jan Wrana ${ }^{2}$ \\ ${ }^{1}$ Department of Faculty of Civil Engineering; Cracow University of Technology; 24 Warszawska \\ Street, 31-155 Cracow, Poland; bwrana@interia.pl (D) 0000-0001-6311-1937 \\ ${ }^{2}$ Department of Faculty of Civil Engineering and Architecture; Lublin University of Technology; \\ 40 Nadbystrzycka Street, 20-618 Lublin, Poland; j.wrana@pollub.pl (DD 0000-0002-4884-0418
}

\begin{abstract}
The buildings of the John Paul II Centre (CJPII) are located in Cracow-Łagiewniki on a heap of limestone sediments from the former "Solvay" Sodium Plant in Kraków. The area is called "Białe Morze" (White Seas) and is located in the natural depression of the Wilga river valley, between Św. Józefa hill in the north and Góra Borkowska hill in the southwest. The limestone sediments as a building substrate for CJPII buildings is unprecedented ground in the world and thus a challenge for civil engineering.

The height of the heap reaches about $15 \mathrm{~m}$ and has retained the consistency of a white pulp until today. CJPII buildings are objects of the third geotechnical category, founded on a foundation slab of $0.8-\mathrm{m}$ thickness, and in the central part of $0.45-\mathrm{m}$ thickness. The slab is based on 200 reinforced concrete CFA-type drilled piles with a diameter of $1000 \mathrm{~mm}$ and $650 \mathrm{~mm}$ and length up to $26 \mathrm{~m}$. The load-bearing structure of the CJPII buildings is a reinforced concrete frame and shell structure.

The symbolism of the urban complex (e.g. the scale of the market square in Wadowice) located on a system of 200 piles, above the post-industrial landfill/heaps of sediments - ensuring its protection by architectural solutions referring to places connected with the life of JPII (the Wawel Cathedral, St. Mary's Basilica in Cracow) with the adopted natural material solutions (brick and white stone) recalling the ways of combining them, and used on the facades of the emerging JPII buildings.
\end{abstract}

Keywords: John Paul II Centre in Cracow, limestone sediments, CFA-type drilled piles, reinforced concrete, natural material solutions, respect for context and identity of the place

\section{Introduction}

The John Paul II Centre complex is set in very unusual geotechnical conditions. Located in Krakow's Łagiewniki district, it is known as the "White Seas". The ground is a massif built of post-production waste from the former "Solvay" Sodium Plant in Cracow, in the form of 
limestone sediments in a plastic state, locally rocked, with a thickness of up to $20 \mathrm{~m}$. The surface of the area has been subject to reclamation by laying about $0.5 \mathrm{~m}$ of soil.

According to the Polish pile standard (PN-83/B-02482), the layer of sediments was regarded as a non-built embankment with zero load capacity. The monumental character of the investment was not without significance here - it was one of the most important factors why the designer of the foundation decided to take such far-reaching precautions. The Polish standard and Eurocode 7 (PN-EN 1997-1 and 2) were used to design the foundation. For the purposes of the project, the testing of the substrate was extended to CPTU static test. The level of foundation was assumed in the layers of native soils, located below the embankments. The following pictures Fig. 1 to 3 show archival photographs of the "White Seas" area.

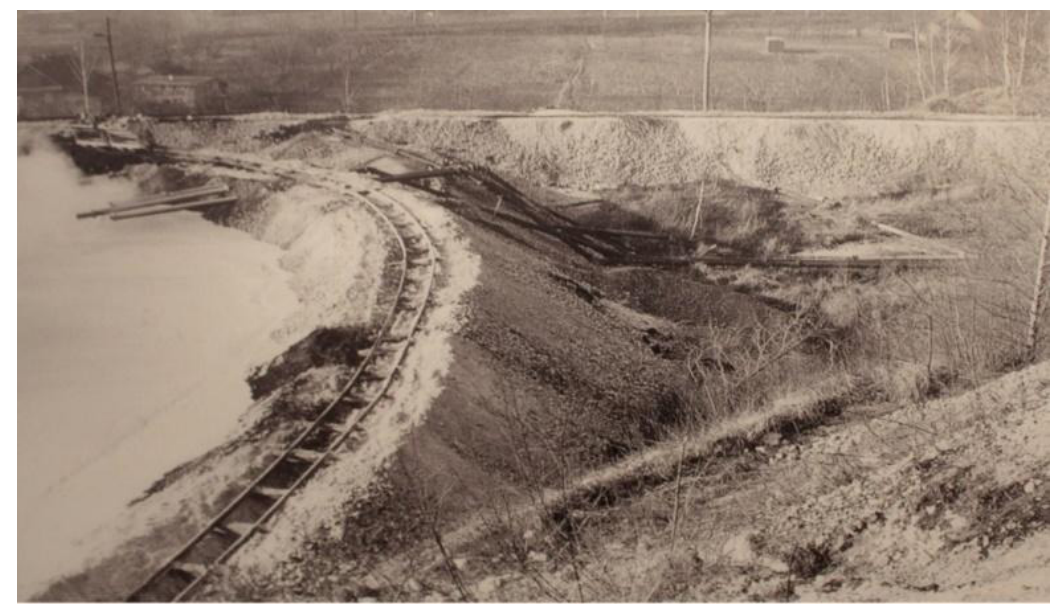

Fig. 1. White Seas in the 1970s. Source: the archive of Bogumił Wrana

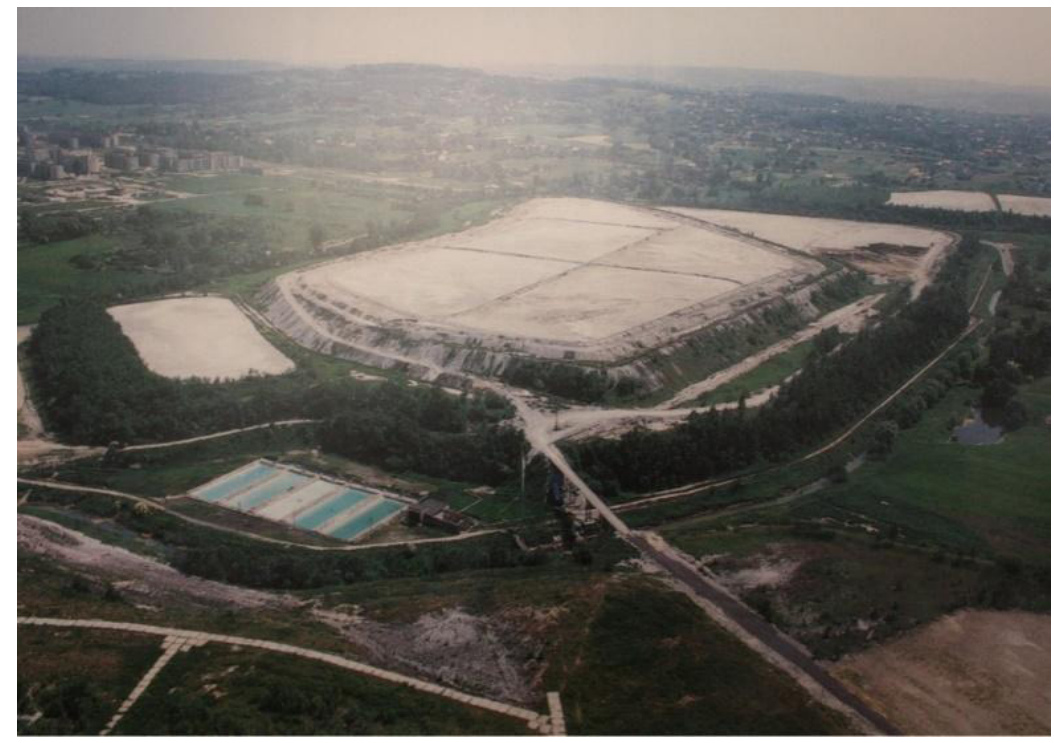

Fig. 2. White Seas in the 1990s. Source: the archive of Bogumił Wrana 

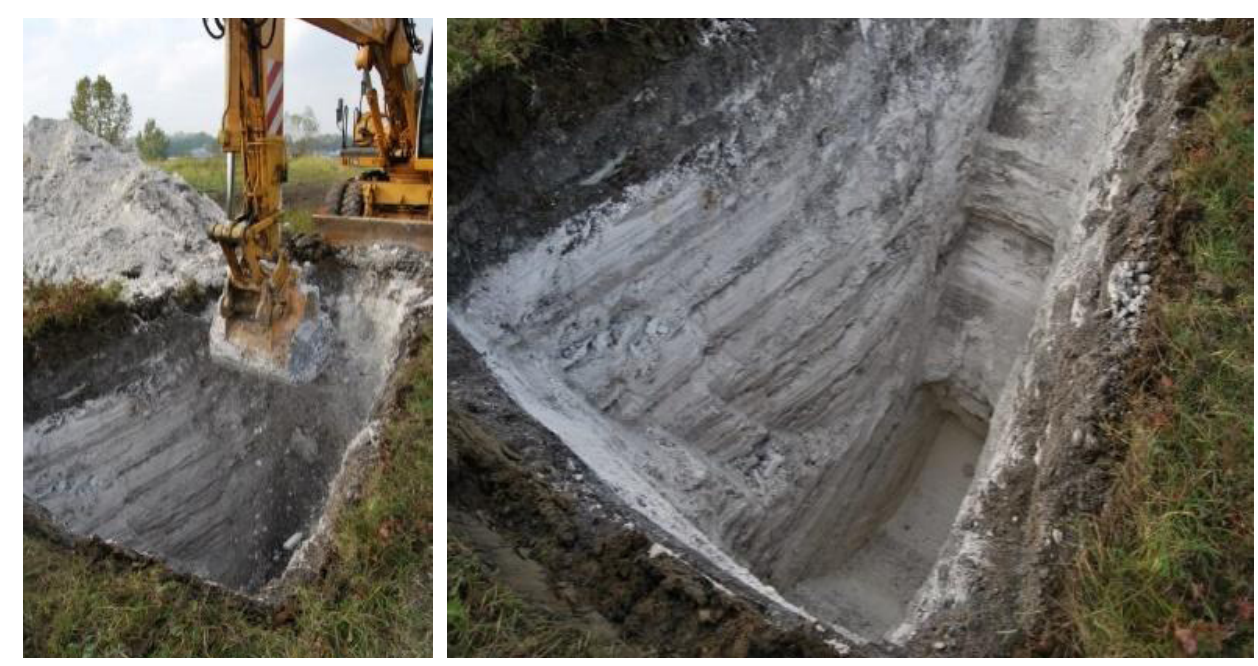

Fig. 3. The ground before starting construction works. Source: the archive of Bogumił Wrana

\section{Geotechnical parameters of soil}

\section{Test drillings}

As part of the field research, 6 holes were drilled with the rotary-percussive system using a mechanical drilling rig in casing pipes with a diameter of $\varnothing=225 \mathrm{~mm}$ in the depth range from $26.0 \mathrm{~m}$ to $33.0 \mathrm{~m}$. Soil samples were taken every $2 \mathrm{~m}(\mathrm{Nu}-$ from non-cohesive soils, NW - from cohesive soils). Soil samples had a volume of about $1.0 \mathrm{dm}^{3}$. Soil samples of intact structure (NNS) were taken from limestone and cohesive soils for laboratory tests of mechanical parameters.

CPT static penetration test was performed in 7 research profiles in the depth range from $14.3 \mathrm{~m}$ to $22.7 \mathrm{~m}$ BGL The interpretation of the soil profile (division into cohesive and non-cohesive soils) was performed according to Robertson's nomogram [1986], while the soil types were determined taking into account the adjacent drilling profiles and the measured values of the friction coefficient $R_{\mathrm{f}}$. For the limestone sediments, the undrained shear strength $s_{\mathrm{u}}$ was calculated.

\section{Hydrogeological conditions}

In the analyzed area there is one quaternary aquifer related to sand and gravel formations of river accumulation. The water table is slightly stretched by silt layers drilled at the depth of $15.3 \mathrm{~m}$ to $24.1 \mathrm{~m}$. Chemical analysis of the water sample showed slight concentrations of heavy metals (chromium, zinc, copper, nickel, lead). The water had a weak level of chemical aggressiveness in relation to concrete.

\section{Division into geotechnical layers}

Four main geotechnical layers were distinguished:

Geotechnical layer I - anthropogenic soils formed as part of the development of a limestone landfill. This layer includes about $0.3 \mathrm{~m}$ to $0.5 \mathrm{~m}$ of humus and sand, rubble and slag embankment in the OW-3 borehole to the depth of $4.2 \mathrm{~m}$.

Geotechnical layer II - limestone sediments heterogeneous in terms of composition and density. The sediments are characterized by the CPT cone resistance $q_{\mathrm{c}}=2-3 \mathrm{MPa}$, locally 
occurring layers with values $q_{\mathrm{c}}=10-20 \mathrm{MPa}$. The results of strength testing of sediments indicate that they are low-strength soils. Moreover, their high sensitivity to changes of humidity should be taken into account. Under the influence of water, they quickly become plasticized, which causes a deterioration of strength parameters.

Geotechnical layer III - Wilga river sediments located directly under the limestone sediments with a thickness of about $10 \mathrm{~m}$. Within this layer, four sublayers were separated:

(Layer III a) - silt, locally peat in the hard plastic state $I_{\mathrm{L}}=0.25$;

(Layer III b) - clay, silt with sand intercalations, locally silt in the hard plastic state $I_{\mathrm{L}}=0.0-0.1$;

(layer III c1) - medium sands, with clays intercalations, in the medium-dense state $I_{\mathrm{D}}>0.6$;

(layer IIIc2) - medium density sand gravels and clayey sand-gravel mix, $I_{\mathrm{D}}>0.6$.

Geotechnical layer IV - Miocene silt developed as silt, silt, compact clay, clay.

\section{Solution of building foundations}

The following method of building foundation was adopted:

a) The St. John Paul II Church - a third geotechnical category building, founded on a foundation slab which is $0.8 \mathrm{~m}$ thick, and in the middle part $0.45 \mathrm{~m}$ thick. The slab is based on CFA type drilled piles with a diameter of $1000 \mathrm{~mm}$ and $650 \mathrm{~mm}$ and a length of up to $23 \mathrm{~m}$. Due to the importance of the building and weak soil in layer II (limestone sediments), the piles are embedded in layer III, carrying the full permanent and usable load of the building.

b) The Volunteer Centrebuilding - a third geotechnical category building, founded on a $0.8 \mathrm{~m}$ thick foundation slab. The slab is based on CFA-type drilled piles of $650 \mathrm{~mm}$ diameter and $23 \mathrm{~m}$ length. Due to weak soil in layer II (limestone sediments), the piles are submerged in layer III, carrying the full permanent and usable load of the building.

c) The Institute building - a third geotechnical category object, founded on a $0.8 \mathrm{~m}$ thick foundation slab. The slab is based on CFA type drilled piles of $650 \mathrm{~mm}$ diameter and $23 \mathrm{~m}$ length. Due to weak soil in layer II (limestone sediments), the piles are submerged in layer III, carrying the full permanent and usable load of the building. 


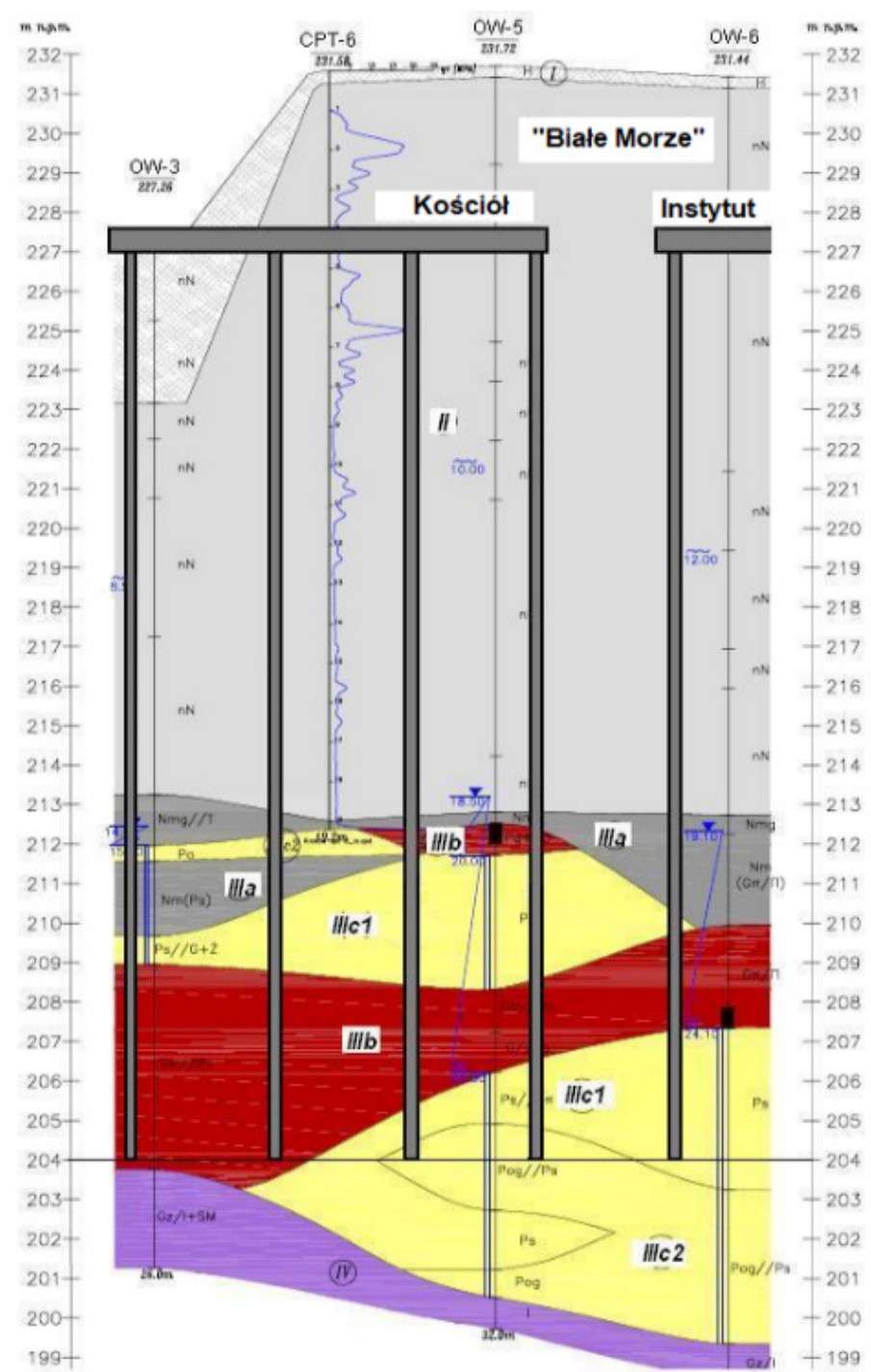

Fig. 4. Geotechnical cross-section with foundations of John Paul II Centre facilities (The church, White Seas, The Institute). Source: the archive of Bogumił Wrana. (glossary see to side. no 3)

\section{Load-bearing system}

The load-bearing system of the buildings is a reinforced concrete slab-column-disk system with stiffening walls, staircases with a lift shaft and a system of transverse and longitudinal reinforced concrete walls. The layout of the walls has been adapted to the layout of the rooms approved in the construction design. The thickness of reinforced concrete walls: external $30 \mathrm{~cm}$, internal $25 \mathrm{~cm}$ and $20 \mathrm{~cm}$ of $\mathrm{C} 30 / 37$ concrete.

The construction of the underground part consists of external reinforced concrete walls $35 \mathrm{~cm}$ and $30 \mathrm{~cm}$ thick, internal reinforced concrete walls $30 \mathrm{~cm}, 25 \mathrm{~cm}, 20 \mathrm{~cm}$ thick and reinforced concrete pillars. 


\section{Foundation of the buildings}

Table 1 presents the type of foundation of the John Paul II Centre buildings.

Table 1. Foundation of the buildings of the John Paul II Centre

\begin{tabular}{lll}
\hline Building & The area of foundation slab & Volume of concrete \\
\hline The church & $\begin{array}{l}80 \mathrm{~cm} \text { thick slab }-1910 \mathrm{~m}^{2} \\
45 \mathrm{~cm} \text { thick slab }-560 \mathrm{~m}^{2}\end{array}$ & $1780 \mathrm{~m}^{3}$ \\
\hline John Paul II Institute & $80 \mathrm{~cm}$ thick slab $-1400 \mathrm{~m}^{2}$ & $1120 \mathrm{~m}^{3}$ \\
\hline The Volunteer Centre & $80 \mathrm{~cm}$-thick slab $-592 \mathrm{~m}^{2}$ & $474 \mathrm{~m}^{3}$ \\
\hline Total & $4462 \mathrm{~m}^{2}$ & $3374 \mathrm{~m}^{3}$ \\
\hline
\end{tabular}

The slabs are based on CFA type drilled reinforced concrete piles with a diameter of $650 \mathrm{~mm}$ and $1000 \mathrm{~mm}$ of C30/37 concrete with a length of $26.0 \mathrm{~m}$.
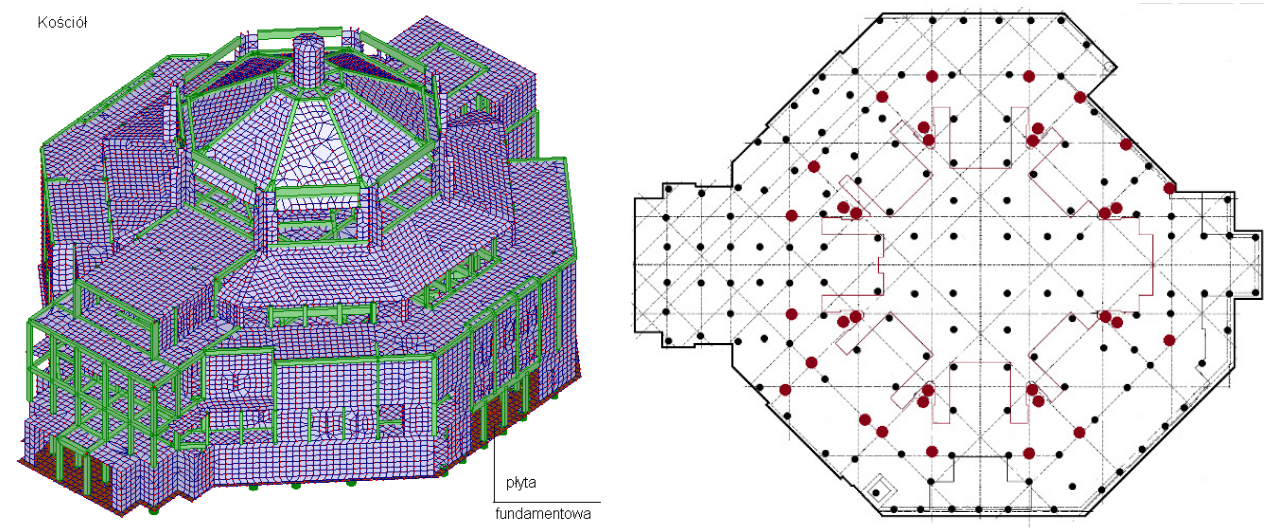

Fig. 5a. The church. Source: the archive of Bogumił Wrana. (see to table no 2)
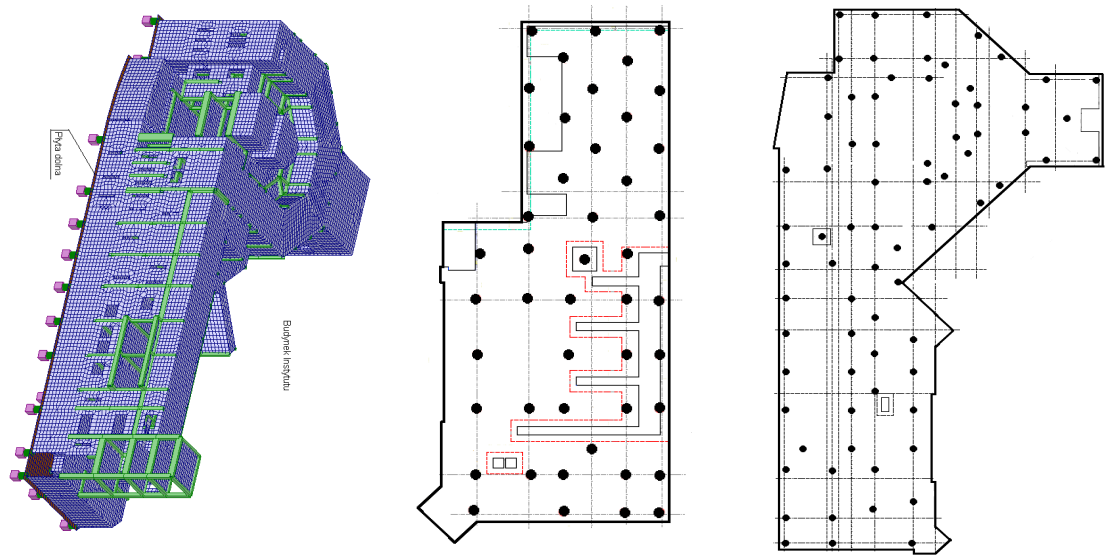

Fig. 5b. The Centre building. Source: the archive of Bogumił Wrana. (see to table no 2)

Fig. 5c. The Institute building. Source: the archive of Bogumił Wrana. (see to table no 2) 


\section{Test plot - pile bearing capacity test}

The standards for calculating the load bearing capacity of foundation piles are based on the results of field tests of the load bearing capacity of many thousands of piles. In the case of untypical construction soil, occurring only in particular areas, the design standards do not provide a credible way to determine the load bearing capacity.

The area of the White Seas has an atypical, particular soil. In this case, it was proposed that piles were constructed, and their load-bearing capacity were tested in the area of the future investment before the commencement of the design and construction process. It was proposed to construct test piles in the area of the future investment. The soil layers were removed up to the foundation level and 7 test piles and 10 retractable piles were constructed for the load-bearing capacity test.

The following test piles were made:

- in CFA technology: 2 piles $\Phi=650 \mathrm{~mm} ; 2$ piles $\Phi=800 \mathrm{~mm} ; 1$ pile $\Phi=1000 \mathrm{~mm}$;

- in VDP technology (Vibrex): 2 piles $\Phi=408 \mathrm{~mm}$;

- 10 retractable piles $\Phi=650 \mathrm{~mm}$.
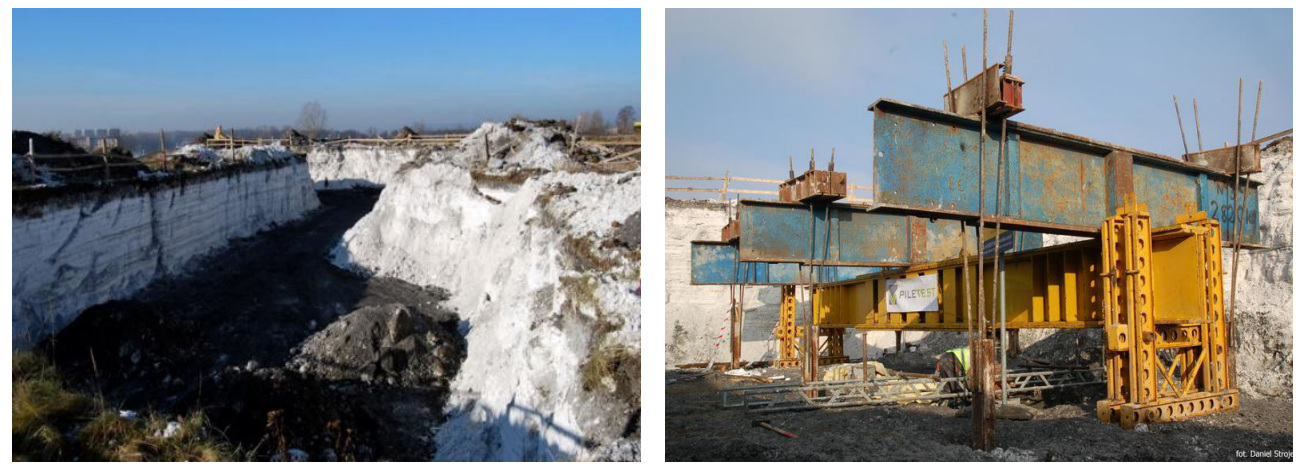

Fig. 6. Test plot - pile bearing capacity testing. Source: the archive of Bogumił Wrana. (see above)

Table 2 below presents the results of the load bearing capacity tests of test piles.

Table 2. Results of load bearing capacity tests of piles

\begin{tabular}{llllllll}
\hline Pile no. & P3 & P4 & P2 & P6 & P5 & P1 & P7 \\
\hline Production technology & CFA & CFA & CFA & CFA & CFA & VDP & VDP \\
\hline Diameter $[\mathrm{mm}]$ & 650 & 650 & 800 & 800 & 1000 & 406 & 406 \\
\hline Length $[\mathrm{m}]$ & 23.0 & 23.0 & 23.0 & 23.0 & 23.0 & 15.0 & 23.0 \\
\hline Max. force during the test $Q_{\text {test }}[\mathrm{kN}]$ & 3500 & 3500 & 4400 & 4400 & 5100 & 2250 & 3000 \\
\hline Subsidence at force $100 \% N_{\mathrm{t}}[\mathrm{mm}]$ & 1.89 & 2.93 & 1.78 & 2.19 & 1.44 & 10.23 & 2.59 \\
\hline Permanent subsidence after the cycle I $[\mathrm{mm}]$ & 0.44 & 1.46 & 0.55 & 0.81 & 0.32 & 5.88 & 0.57 \\
\hline Subsidence at force $Q_{\text {test }}[\mathrm{kN}]$ & 9.88 & 16.23 & 7.57 & 14.01 & 6.05 & 49.55 & 13.78 \\
\hline Permanent subsidence after the cycle II $[\mathrm{mm}]$ & 5.14 & 11.09 & 3.55 & 9.90 & 3.57 & 42.41 & 6.99 \\
\hline $\begin{array}{l}\text { Measured load bearing capacity of the pile } \\
N_{\mathrm{k}}[\mathrm{kN}]\end{array}$ & 2844 & 2406 & 3575 & 3300 & 4144 & 1688 & 2063 \\
\hline
\end{tabular}




\section{Results of calculations of pile load bearing capacity}

\section{Calculations according to Polish standards}

On the grounds of the recorded resistance under the $q_{\mathrm{c}}$ cone, the values of soil parameters were determined based on correlations according to PN-B-04452:2002. The layer of limestone embankment, which lies at a depth of $17.5 \mathrm{~m}$ BGL, was treated as cohesive soil of plastic and soft plastic consistency. Based on the $I_{\mathrm{D}}$ and $I_{\mathrm{L}}$ parameters determined in accordance with the Polish standard PN-83/B-02482, unit values of resistance under base $q$ and along the pile shaft $t$ were assumed. The base of the piles was placed at a depth of approx. $26.0 \mathrm{~m} \mathrm{BGL}$, in a layer of medium-density sands. The pile was, therefore, submerged at a depth of approx. $8.5 \mathrm{~m}$ in the native soil layer.

\section{Calculation according to Eurocode 7}

The calculation procedure presented in Annex D.7 of EN 1997-2 uses directly measured resistance values $q_{\mathrm{c}}$ under the static probe cone. Soils with $q_{\mathrm{c}}$ value less than $2.0 \mathrm{MPa}$ are considered as non-bearing layers. The final load bearing capacity of the pile under consideration is $R_{\mathrm{c} ; \mathrm{d}}=2632 \mathrm{kN}$, including load bearing capacity of the base $R_{\mathrm{b} ; \mathrm{d}}=2280 \mathrm{kN}$ and load bearing capacity of the shaft $R_{\mathrm{s} ; \mathrm{d}}=352 \mathrm{kN}$.

\section{Analysis of the results}

The difference in the results of the calculations performed by the two standard procedures is significant. The design procedure according to Polish standards estimates the load bearing capacity of an exemplary pile at the level twice lower than the Eurocode 7 procedure using directly the CPT test results. The main reason for the differences is the way of using the results of static tests for the evaluation of soil parameters. The direct use of static test results for the assessment of unit resistance of the base and side of the pile, established in the Eurocode 7 procedure, leads to higher values of these parameters. It should be noted that the higher value of the total load capacity of the pile was influenced by the load bearing capacity of the pile base, resulting directly from the assumed values of unit resistance, which for Polish standards is only $q=1.71 \mathrm{MPa}$, while according to Eurocode $7 p_{\text {max;base }}=6.99 \mathrm{MPa}$

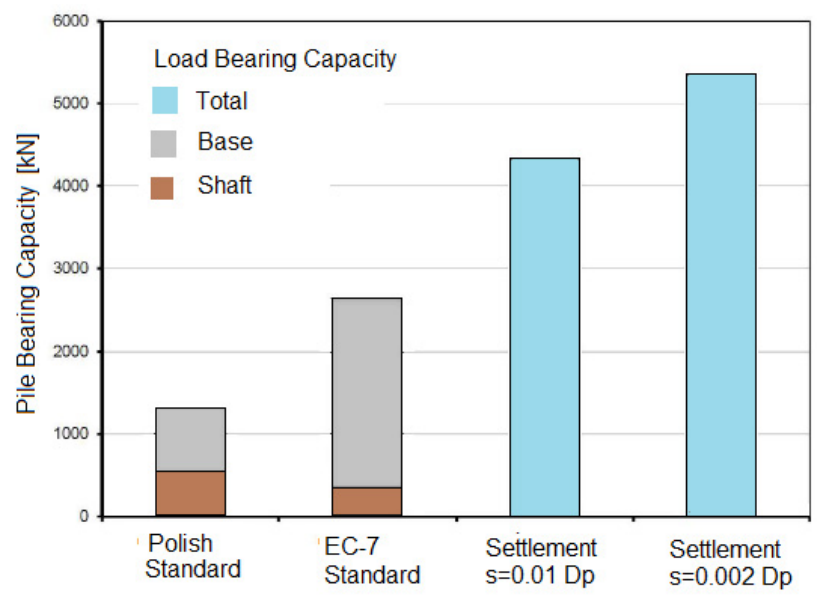

Fig. 7. The comparison of results of the load bearing capacity tests. Source: the archive of Bogumił Wrana 
The assessment of the load bearing capacity of the pile shaft turned out to be more cautious according to Eurocode - the lowest non-bearing layer was located here at a several meters lower level than according to Polish standards.

The figure 7 shows a comparison of the design load bearing capacity of the pile determined according to the Polish standard and the European standard. In the investigated soil conditions of White Seas area, the design pile load bearing capacity according to the European standard is much higher than according to the Polish standard. The measured load bearing capacity of the pile, in the load bearing capacity test carried out in the area of the test plot, turned out to be higher than the load bearing capacity calculated according to the standards.

\section{The John Paul II Centre (CJP II)}

The area where the John Paul II Centre (CJP II) has been constructed since 2008 is located, according to the current administrative division of the city, in the district IX of Kraków; Łagiewniki-Borek Fałęcki.

Łagiewniki is the first part of the current IX district of Kraków (a village located on the bank of the Wilga river, basin of the Vistula river, the name of which has been mentioned since 1373) as a knight's property. From the late fifteenth century, the area has belonged to the Castellan of Cracow (the manor buildings preserved to this day date back to the nineteenth century). Until the $18^{\text {th }}$ century, the village was managed by leaseholders; in the second half of that century, the imperial route from Vienna to Lviv was marked out by Lagiewniki and Borek Fałęcki (nowadays it is Zakopiańska Street - an exit road in the direction of Zakopane). The second part of District IX is the area of the village of Borek Fałecki (the name comes from coniferous forests with the dominating Góra Borkowska hill, first mentioned in 1392. After the First Partition of Poland, the village became a private property, where in the $19^{\text {th }}$ and $20^{\text {th }}$ centuries the industry developed (as a result of discoveries of shale clay and gypsum, limestone. Due to this fact, numerous brickyards, mills and industrial plants we-re built. During the period of the Austro-Hungarian partition, an "industrial zone" was created on the south of the Vistula (in the vicinity of the then Dębniki -the present districts of XI Podgórze, and IX Łagiewniki -Borek Fałęcki). At the end of the $19^{\text {th }}$ century, a section of the railway line to Oświęcim runs through Borek Fałęcki with Borek Fałęcki stop.In 1901,Pierwsza Galicyjska Fabryka Sody Amoniakalnej S.A.” (First Galician Soda Ash Factory S.A.) was established in this area (near the rich deposits of limestone -a raw material for the production of sodium), and after obtaining permission, was launched in 1906 by Bernard Lebanon. Three years later, he leased the factory to the Belgian concern "Solvay". (Ernest Solvay $1838-1922$, is chemist, inventor, industrialist). The expanded plant, after the completion of a narrow w gauge railway line in 1918 for transport of the raw material from a distance of $4 \mathrm{~km}$ (quarry in Zakrzówek - the current district of Dębniki), was bought by the Solvay concern in 1921. The management of the expanded plant decides to buy the parcel of land by the Wilga river, where it started storing white waste. After a few dozen years, a high embankment was built in the area called "White Seas" by the inhabitants of Cracow. After the change of the political system, as a result of an assessment during which it was found that the factory had been heavily polluting the environment, it was liquidated between 1989-1996. During the occupation, the sodium factory was transformed into Ostdeutsche Chemische Werke GmbH, employing German managers. Karol Wojtyła, a student living with his father in neighbouring Dębniki at 10 Tyniecka Street -15 minutes from the Wawel Cathedral, after interrupting his Polish studies in 1939 (started in 1938 at the Jagiellonian University), initially began working as a shop messenger, and since September 1940 in 
a quarry in Zakrzówek (it should be mentioned that employment in the German factory protected him from being transported to the Reich for forced labour). On February $18^{\text {th }}$ 1941 Karol Wojtyła's father died. At the age of less than 21, he became an orphan (at the age of 9 he lost his mother and at the age of 12 he lost his older brother). In the summer of 1941 Wojtyła moved from the quarry to the factory in Borek Fałęcki ${ }^{1}$. In 1944 he stopped working in the Solvay factory (earlier, in October 1942, he started studying at the secret classes of the Jagiellonian University.

A house that Karol Wojtyla never had; In Wadowice he lived in a rented apartment, in Cracow as a student-somewhere in the basement of a house belonging to a relative on the side of Emilia's mother, as a priest he resided in the parish, as a bishop in the curia, and as Pope at the Apostolic Palace... ${ }^{2}$ - currently, it's called the House of St. John Paul II

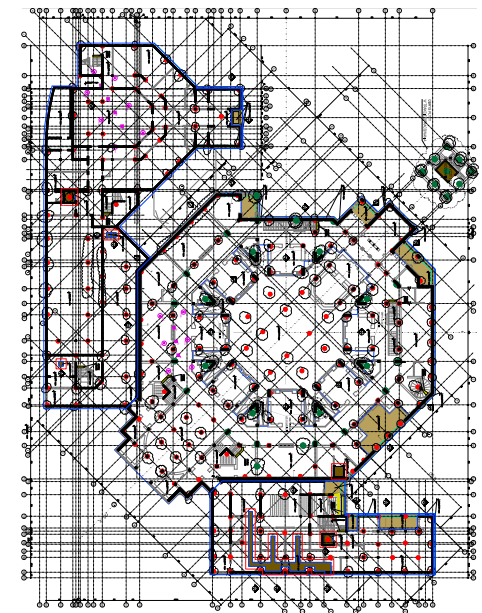

Fig. 8.1 Foundation lower slab (on the pillars) of the main unit (part of the urban complex); a. The church, b. The Centre building, c. The Institute building. Source: the archive of Bogumił Wrana

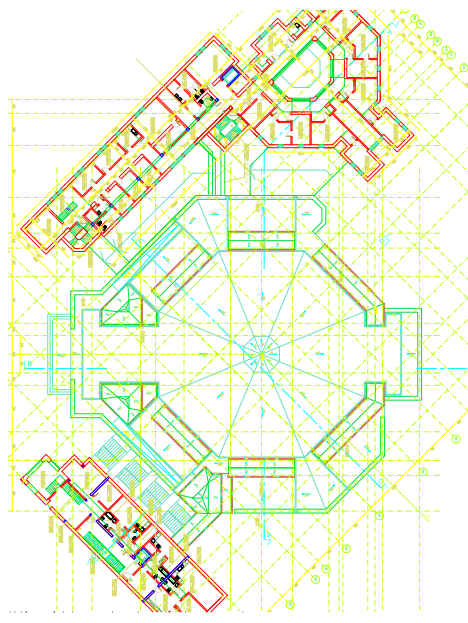

Fig. 8.2. Foundation upper slab of the main unit (part of urban complex); a. The church, b. The Centre building with marked pile spacing, c. The Institute with sketched buildings. Source: the archive of Bogumił Wrana

The symbolism of the urban complex (e.g. the scale of the market square in Wadowice) located on a system of 200 piles, above the post-industrial landfill/heaps of sediments ensuring its protection by architectural solutions referring to places connected with the life of JPII (the Wawel Cathedral, St. Mary's Basilica in Kraków) with the adopted natural material solutions (brick and white stone) recalling the ways of combining them, and used on the facades of the emerging JPII buildings.

1 "His colleagues from those times, whose memories, despite many hardships, were collected by the invaluable Mrs. Karolina Biedrzycka (in the book „Ten człowiek w drewniakach. Solvay 1940-1944”), stressed that Karol was always modest and quiet, very calm, thoughtful and serious, actually too serious for his age. He always walked with his head, in too big a shirt and clogs without socks. Some people also remembered the rubber jacket he was wearing." [after:] A. Bujak, J. Sosnowska, Dom Świętego. Sanktuarium św. Jana Pawła II, Wydawnictwo Biały Kruk sp. z o.o. Kraków 2015.

2 Ibid. p. 21 
Solutions in terms of colours and materials, (evoking places connected with the life of JP II): (Figs. 8.1, 8.2, 9.a, 9.b, 9.c, 10.a, 10.b, 10.c, 11.a, 11.b, 11.c) 2. and inspirational of interior mosaics (Figs. 12.a, 12.b, 12.c, 12.d, 13.a, 13.b, 13.c, 13.d).

a)

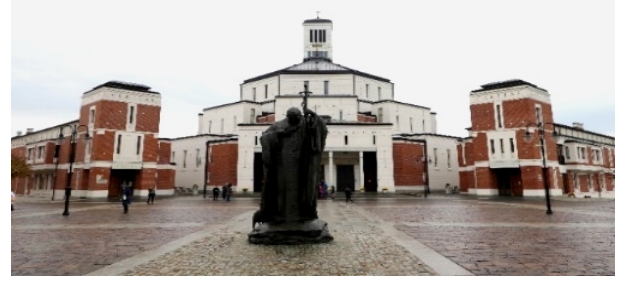

c)

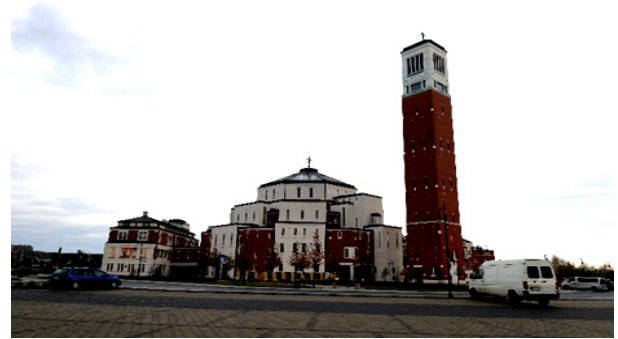

b)

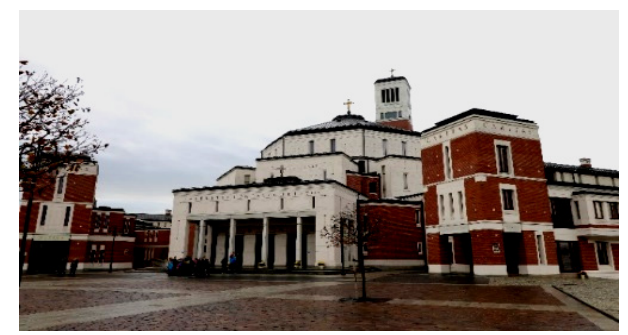

d)

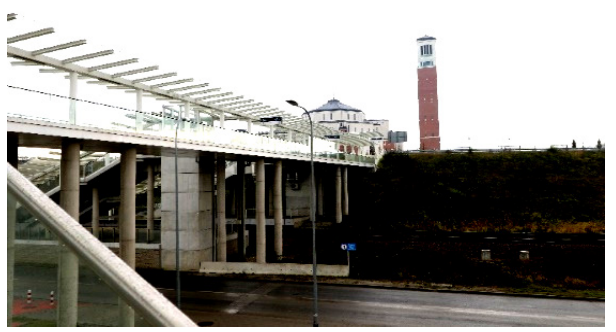

Fig. 9. a, b, c The John Paul II Centre, first buildings: St. John Paul II Sanctuary, the Volunteer Centre, the John Paul II Institute of Intercultural Dialogue and a tower with a terrace and bell. Fig d. Direct communication by tram, bus, car (a route with a tunnel under Zakopiańska Street under construction (Source: own photographs of J. Wrana). Source: the archive of Jan Wrana

a)

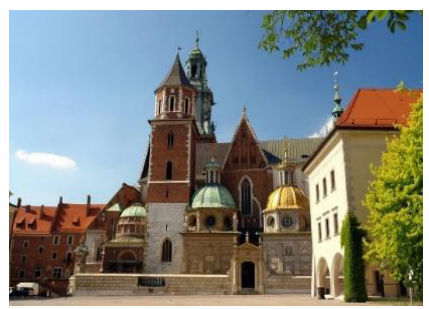

b)

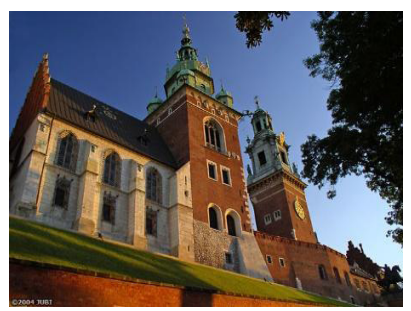

c)

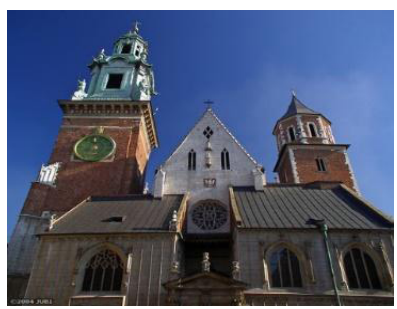

Fig. 10. The Wawel Cathedral

a)

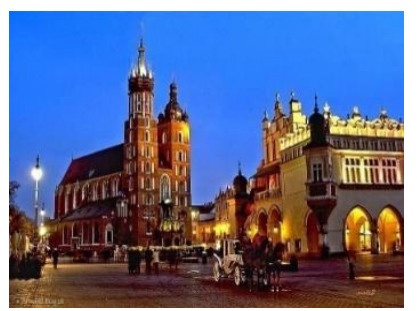

b)

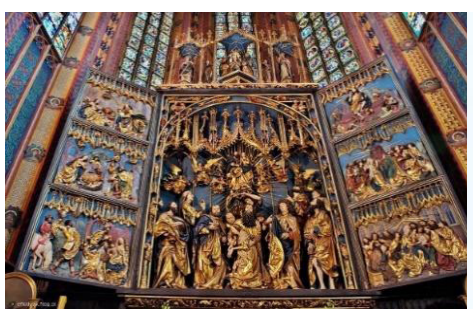

c)

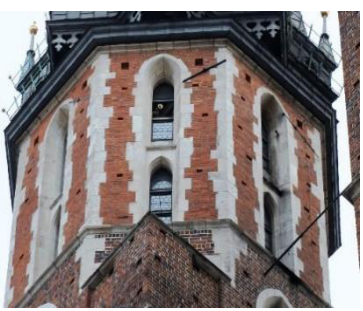

Fig. 11. St. Mary’s Basilica 
a)

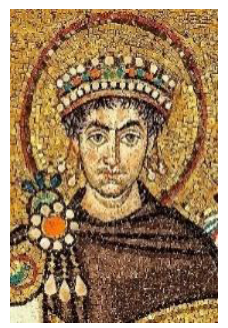

b)

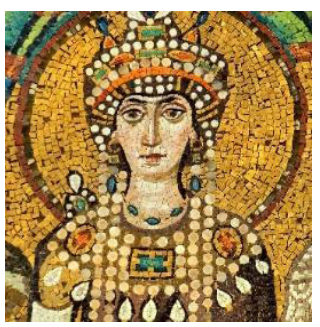

c)

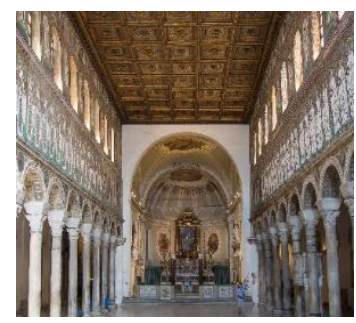

d)

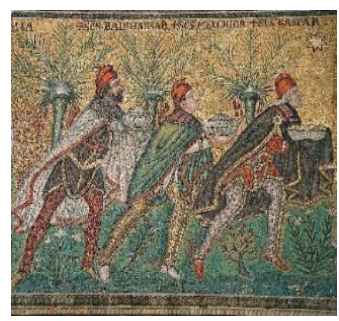

Fig. 12. Inspirational mosaics - early Christiam mosaics (the church of San Vitale and Basilica of Sant' Apollinare Nuovo in Ravenna) on the way of creating contemporary mosaic decoration of the "theology of mosaics" temples by mosaic author Marko Ivan Rupnik at the JPII Centre

a)

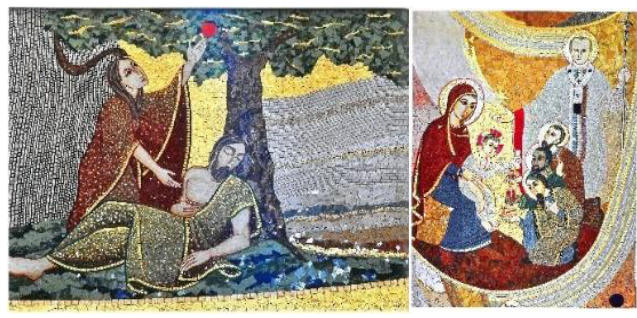

c)

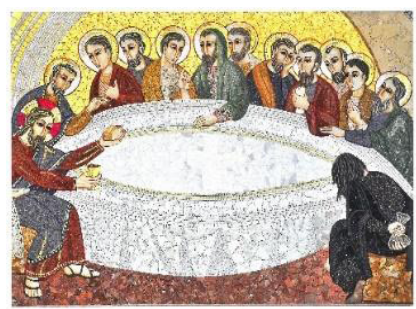

d)

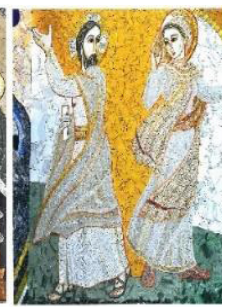

Fig. 13. Mosaic in the JPII Centre Sanctuary

The newly established "Have No Fear" John Paul II Centre is a continuation of the work started by the John Paul II Institute, established in 1995 by Cardinal Franciszek Macharski in order to "deepen the knowledge of the Person and work of Cardinal Karol Wojtyła, professor of ethics and shepherd of the Archdiocese of Cracow"3.

The "Have No Fear" John Paul II Centre is being built on an area formed from the post-production sludge of the former "Solvay" Sodium Plant ${ }^{4}$ - the limestone sediments as a construction base for the CJPII buildings is an unprecedented ground in the world and has thus became a challenge for civil engineering, but on the other hand, it is a very important symbol of the complex - referring to the words "You are a rock". It built a permanent independent foundation for the "Good Shepherd" house with inspiration / architectural and material solutions (brick and white stone) evoking places connected with the life of JPII (tenement houses in Dębniki and Podgórze in Kraków, the Wawel Cathedral, St. Mary's Basilica, tenement houses on Kanonicza Street, early Christian temples in Ravenna and Venice, Archbasilica of St John Lateran, St. Peter's Basilica in Rome proposed by Andrzej Mikulski - graduated from the Cracow University of Technology. The way of creating contemporary mosaic decoration of the temples, "theology of mosaics", by mosaic author Marko Ivan Rupnik in the JPII Centre.

"The main institutions of the Centre that were established until 2019: "The John Paul II Sanctuary, the Volunteer Centre, the John Paul II Institute of Intercultural Dialogue, a tower with

Ibid. p. 24

4 Ibid. p. 24 
a viewing terrace and bell tower, and the Museum building. The next stages will be: Pilgrim's House, Retreat House, Conference Centre and Rehabilitation Centre"."

Due respect for the work of Karol Wojtyla and his friends - workers in Solvay during the war - is expressed by the preserving the steel footbridge (once a technological bridge for the transport of waste) connecting the Centre's grounds with the rest of White Seas and the direction of the pedestrian route which it marks. ${ }^{5}$

\section{References}

[1] Wrana B., Projekt budowlany posadowienia obiektów Centrum Jana Pawła II na „Białych Morzach”. BOMES, Kraków, 2009.

[2] Czado B., Domski J., Wrana B., „Optymalizacja posadowienia palowego obiektów Centrum Jana Pawła II w Krakowie-Łagiewnikach", in Materiaty Seminarium IBDiM i PZWFS Wzmocnienie podłoża i fundamentów, Warszawa, 2014.

[3] Wrana B., Czado B., „Zastosowanie wyników testu CPT do oceny nośności pala”, Górnictwo $i$ Geoinżynieria, vol. 35, no. 2, pp. 605-611.

[4] Wrana B., Lectures on Soil Mechanics. Wydawnictwo Politechniki Krakowskiej, Kraków, 2014.

[5] Wrana B., Lectures on Foundation Design. Wydawnictwo Politechniki Krakowskiej, Kraków, 2016.

[6] Wrana B., „Pile load capacity - calculation methods”, Studia Geotechnica et Mechanica, vol. 37, no. 4, 2015, pp. 83-93.

[7] Robertson P.K., Campanella R.G., Gillespie D., Greig J., "Use of piezometer cone data", in Proceedings of the ASCE Specialty Conference In Situ '86: Use of In Situ Tests In Geotechnical Engineering, pp. 1263-1280, Blacksburg, 1986.

[8] EN 1997-1, Eurocode 7: Geotechnical design - Part 1: General rules.

[9] EN 1997-2, Eurocode 7: Geotechnical design - Part 2: Ground investigation and testing.

[10] PN-B-02482:1983 - Fundamenty budowlane. Nośność pali i fundamentów palowych.

[11] ISO 14688-1: Geotechnical investigation and testing - Identification and classification of soil - Part 1: Identification and description.

[12] ISO 14688-2: Geotechnical investigation and testing - Identification and classification of soil Part 2: Principles for the classification.

[13] Wrana J., Tożsamość miejsca - kryterium w projektowaniu architektonicznym. Politechnika Lubelska, Lublin, 2011.

[14] Wrana J., Eseje o tożsamości miejsca. Wybrane artykuly dotyczace tożsamości i kontekstu. Politechnika Lubelska, Lublin, 2012.

[14] Wrana J., „Architektura - zrozumiały komunikat przestrzenny”, Czasopismo Techniczne, PK, no. 15, 2010.

[15] Wrana J., „Architektura z poszanowaniem miejsca”, Budownictwo i Architektura, vol. 9, no. 2, 2011, pp. 129-139.

[16] Wrana J., Fitta A., „Architektura a kontekst miejsca”, Budownictwo i Architektura, vol. 11, no. 1, 2012, pp. 5-13.

[17] Wrana J. Sacrum a nowoczesność - rozważania na przykładzie kościoła św. Stanisława w Krakowie. Wydawnictwo Architecturae et Artibus, vol. 8, no. 3, Białystok, 2016.

[18] de Palol P. et al., Sztuka Świata. Wydawnictwo Arkady, vol. 3, Warszawa, 1970.

5 Ibid. p. 25 
[19] Adamska M., Siewak-Sojka Z. et al., Architektura świata, Architektura wczesnochrześcijańska i bizantyjska. Architektura wczesnego średniowiecza. Wydawnictwo Dragon, Bielsko-Biała, 2011.

[20] Muratow P., Obrazy Włoch. Państwowy Instytut Wydawniczy, Warszawa, 1972.

[21] Bujak A., Sosnowska J., Dom Świętego. Sanktuarium św. Jana Pawła II. Wydawnictwo Biały Kruk, Kraków, 2015.

[22] Dzieje Krakowa, red. Bieniarzówna J., Małecki J., Mitkowski J., vol. 4, Kraków, 1979-1997. 